\title{
SOME FACTORS THAT INFLUENCE THE RATE OF GROWTH OF PASTURE
}

By R. W. BROUGHAM, Ecologist, Grasslands Division,

Department of Scientific \& Industrial Research,

Palmerston North

It is becoming increasingly evident from work carried out by various groups of research workers throughout the world (Thomas and Hill, 1949; Blackman and Wilson, 195 I ; Donald, 1951 , 1956; Black, 1955; Watson, 1956) that the amount of light energy available to herbage and crop plants is a major controlling factor in plant growth. In a recent review article Black ( 1957) has stated, "It is clear from the evidence herein reviewed that the growth-of pasture species, as of other plants, is markedly dependent on the light environment, and that the quantity of light energy available rather than the intensity appears to be the important factor. Apparently the greater the quantity of light energy available up to the highest values recorded in the field, the better the growth."

For this reason, the problem of increasing pasture yield, once nutrients and water are in sufficient quantities to meet all demands by pasture plants, is one of increasing the total amount of photosynthesis per unit area of sward per unit of time. Because the amount of incoming radiation at a given location is relatively constant from year to year, it is therefore necessary to maintain an amount of photosynthesising tissue per unit area of pasture such that all incident light energy is utilised by this tissue. Once this is achieved the rate of dry matter increment will then be at a constant maximum rate.

A considerable amount of indirect evidence is available to support this view. Studies of the influence of various frequencies and intensities of defoliation (Stapledon, 1924; Richardson, Trumble, and Shapter, 1932; Hudson, Doak, and McPherson, 1933; Sears, 1949; Wagner, 1952) on the yields of pastures generally show that lengthened spells between grazings result in increased yields. Part of these increases can be attributed to an increase in the total photosynthetic activity of the pasture associated with the increases in the amount of leaf present with spelling.

More direct evidence has been obtained from an experiment carried out at the Grasslands Division, D.S.I.R. (Brougham, 1956). The results are shown graphically in Fig. 1. 


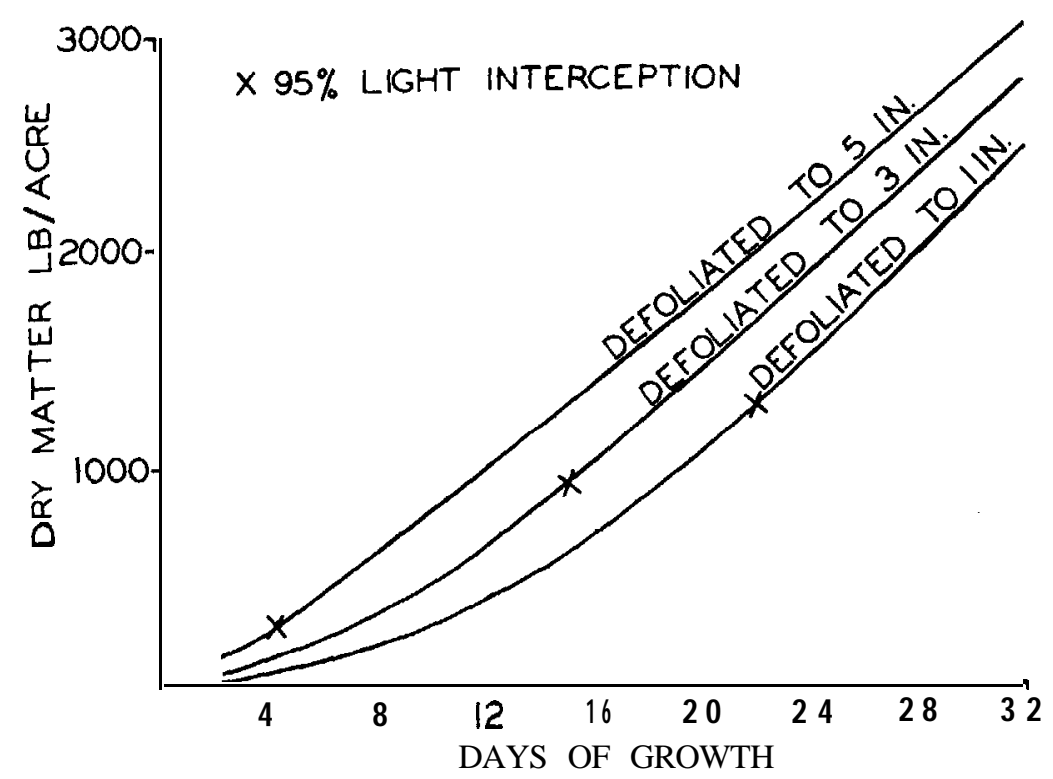

Fig. I-Pasture growth rate after defoliation to different heights. (The stage of regrowth at which 95 per cent. of the light was intercepted is also shown.)

For three swards defoliated to the heights shown, dry matter increase reached a constant maximum rate as soon as all light was intercepted by green leaf. The Leaf Area Index at the point of complete light interception was approximately 5. The term Leaf Area Index refers to the ratio of leaf area to ground area occupied and will be referred to hereafter as L.A.I. The experiment was carried out in the spring on a short-rotation ryegrasswhite clover pasture, the ratio of grass to clover being approximately $75: 25$. These results suggest that complete light interception results in maximum photosynthetic activity per unit area of sward and hence maximum rate of growth.

Similar results to these have recently been published by Watson (1956) from a series of experiments on the growth of the crop plants kale and sugar beet. This work showed that the growth rate of sugar beet was proportional to the amount of leaf present. Using a range of L.A.I. from 0 to 5 , the extrapolated maximum growth rate was estimated to occur between 5 and 6 . For kale, the maximum growth rate occurred at a value of approximately 3 and at higher values it decreased. Although not determined by Watson, the L.A.I. shown as maximal for the growth rate of these two species were probably coincident with the 
stage of growth at which complete light interception occurred.

However, because pasture species exhibit markedly different forms of growth, the amount of leaf required for complete light interception varies with species. For example, leaves of white clover are horizontally placed, except for a phototropic movement during the day which tends to orientate the leaves at right angles to the source of light, whereas ryegrass leaves are long and slender and usually erect throughout most of their lensth. White clover leaves are therefore more favourably placed to intercept light than are ryegrass leaves. This is shown from the results presented in Fig. 2, which were obtained from an experiment in which the relationships between leaf area and light interception in the regrowth of pure and mixed stands of pasture species were examined (Brougham, 1957).

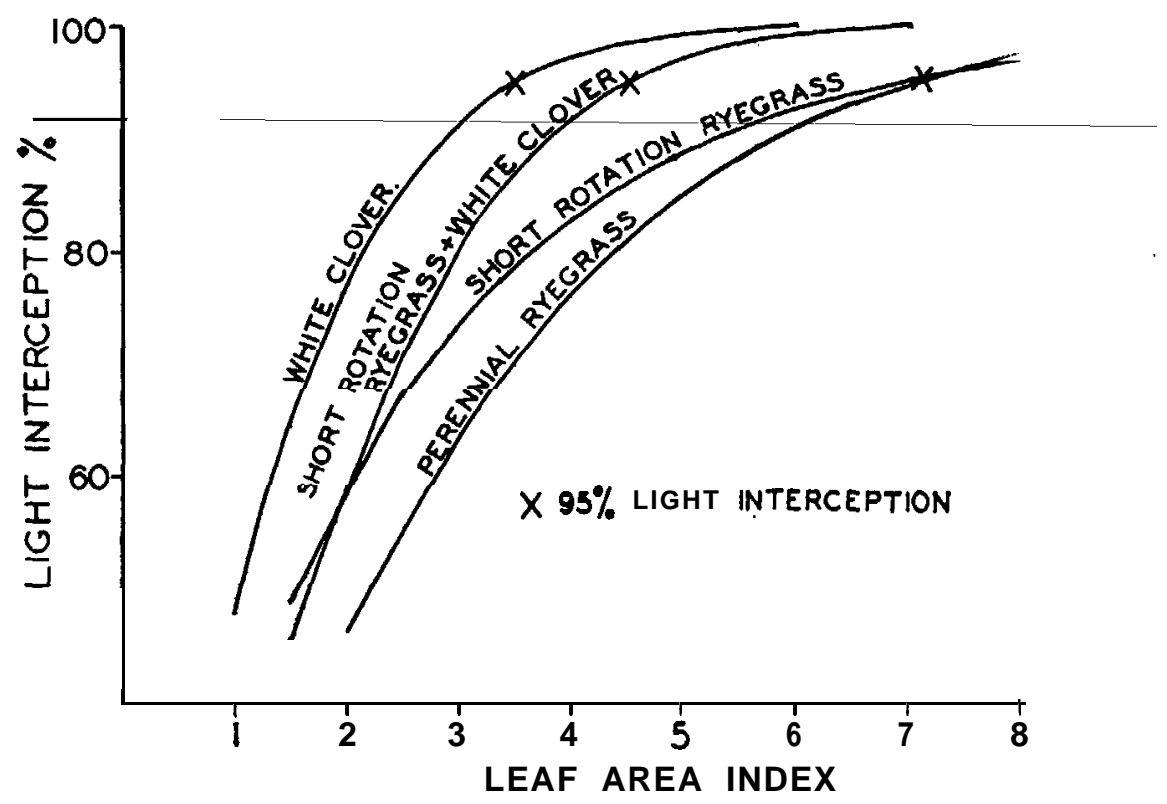

Fig. 2-The relationship between light interception and leaf area index for four stands. (Critical leaf area indices are also shown.)

The critical L.A.I. values obtained for the four stands shown in midsummer were as follows: Perennial ryegrass $(7.1)$, shortrotation ryegrass (7. I ), white clover (3.5), mixed stand (4.5). The ratio of short-rotation ryegrass to white clover in the mixed stand was 50:50. The term critical L.A.I. refers to the amount of leaf required to intercept 95 per cent. of the incident light. 
It can be estimated from these results that the light-intercepting capacity of white clover leaves is approximately 0.5 and for perennial ryegrass 0.25 , with an intermediate value for shortrotation ryegrass. Light-intercepting capacity denotes the proportion of unused light intercepted by successive units of L.A.I. Hence complete utilisation of available light will be obtained by a smaller amount of foliage in white clover stands than in ryegrass stands and it will produce at a maximum rate under closer grazing than grass.

In addition to species variation in the light-intercepting capacities of leaves, the relationship between leaf area and light interception also varies with season. In the above experiment (Brougham, 1957) the amount of light penetrating through the foliage of the four stands at different elevations of the sun on cloudless days in midsummer was also determined. The results obtained showed marked differences at various elevations of the sun and suggested that the amount of leaf of a particular species required to intercept almost all the available light in midwinter was approximately half the midsummer value. Consequently, for maximum growth during the winter, the herbage height at grazing and the amount of herbage left after grazing will be much lower than that required in the summer. Spring and autumn values will be intermediate.

The above results emphasise the importance of maintaining sufficient leaf to intercept all light and hence maintain pasture growth at a miximum rate. They also show that a continually changing relationship exists between light interception and leaf area, being influenced by stage of growth, species, and season of the year. For these reasons, herbage heights of pastures before and after grazing should be varied in accordance with botanical composition and season.

There are many other factors such as tiller density and dispersion, the amount of stored reserves available for immediate regrowth, and the leaf to stem ratio after grazing which influence regrowth of pasture. However, in the time remaining I wish to deal with some factors associated with decreasing growth rates.

It is generally well known that within a pasture competition for light is a dominant factor governing botanical composition of the sward (Blackman and Templeman, 1938). In the ryegrassclover pasture under New Zealand conditions, the grasses usually dominate during the late autumn, winter, and early spring because of their better tolerance of the temperatures that occur at these times (Mitchell, 1956). Under long spelling the clovers are therefore suppressed. This is illustrated in Fig. 3 for a short-rotation 
ryegrass-white clover pasture defoliated to $1 \mathrm{in}$. and then spelled for 18 weeks in the late autumn and winter.

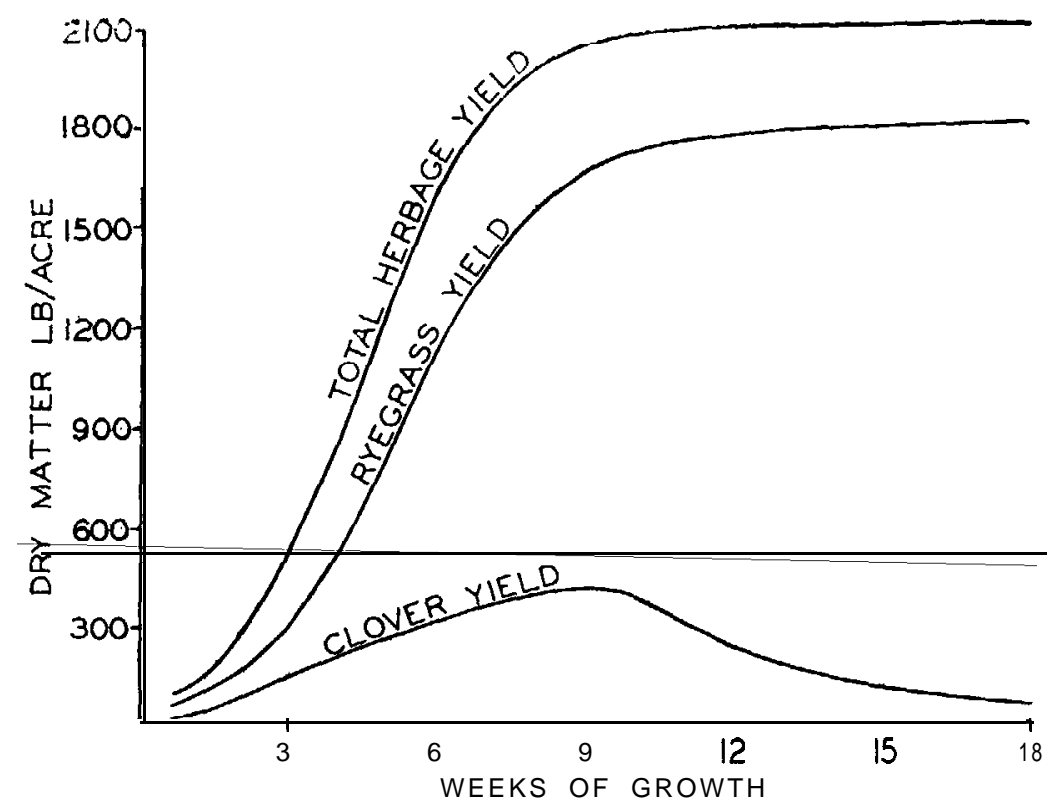

Fig. 3--Kate of growth of total herbage, ryegrass, and clover in a mixed sward during the late autumn and winter.

Initially, the growth rate of ryegrass and clover followed the same pattern, but once all the light was intercepted three to four weeks after defoliation, competition for light became operative and was the dominant factor controlling the growth rate of the clover component. Clover growth rate then began to decline, whereas ryegrass growth rate continued at a constant maximum rate. After a further three to four weeks, the growth rate of ryegrass also began to decline and at 10 weeks increases in growth were negligible. Yield ceilings then remained constant for the remainder of the experiment. For clover, yield decreases were recorded after 10 weeks and at the end of the experiment only a small amount of clover remained. A considerable amount of decomposition of plant tissue occurred after 10 weeks and this would explain the results obtained.

Mitchell's work on the base-shading of short-rotation ryegrass (1955) also illustrates the significance of intra-species competition for light on growth rate and rate of tiller formation. Both were 
markedly reduced when plants were shaded at the base to simulate the light conditions pertaining to a spelled pasture.

Another index used to measure the efficiency of the photosynthetic system of plants and pastures is that of Net Assimilation Rate, which will be referred to hereafter as N.A.R. This term denotes the rate of increase of dry matter per unit leaf area and allows comparisons to be made between rates of apparent photosynthesis of field crops or pastures subjected to different treatments. It also serves as an illustration of the importance of factors such as leaf age, mutual shading of leaves, and the balance between respiration and photosynthesis on growth rate. The interplay of these factors on the N.A.R. of short-rotation ryegrasswhite clover pastures defoliated to three heights is shown in Fig. 4.

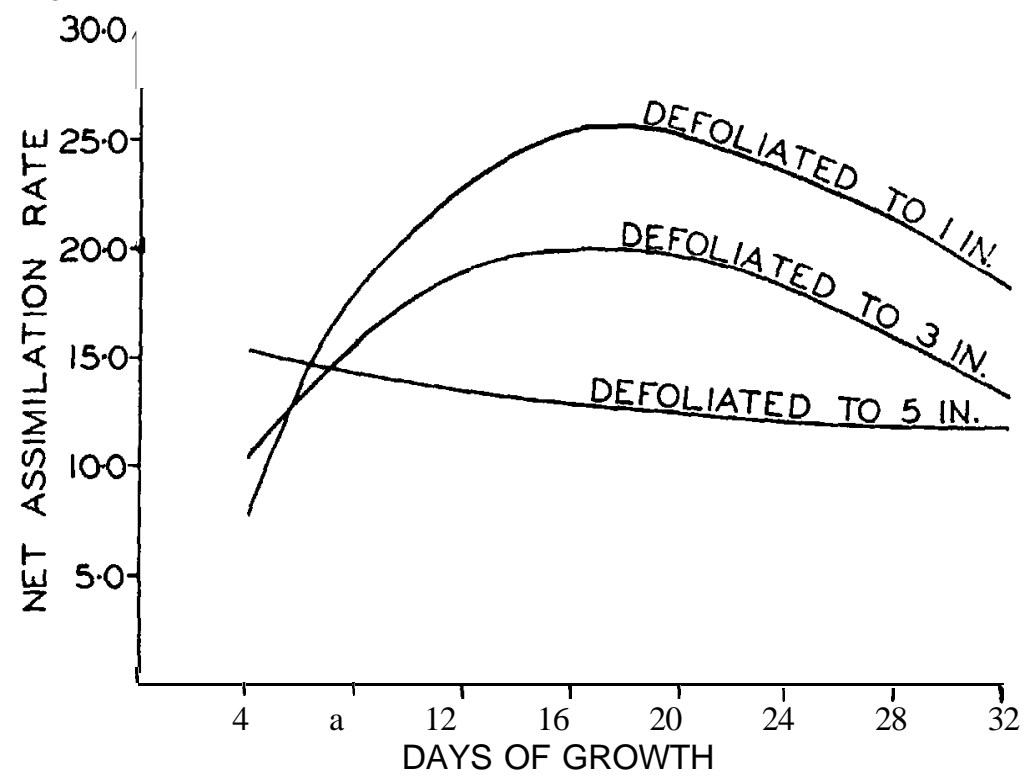

Fig. 4-Net assimilation rate of pastures defoliated to different heights at various stages of regrowth.

Maximum N.A.R. in the 3 in. and $5 \mathrm{in}$. cutting treatments occured at the point of complete light interception, whereas for pasture defoliated to $l$ in. it reached a maximum before complete light interception was obtained. Before this point N.A.R. in all treatments increased rapidly, but beyond it the N.A.R. gradually declined. The initial values of N.A.R. were dependent on the intensity of defoliation, the lowest value shown being obtained from the most severe defoliation. 
These changes in N.A.R. can be interpreted as follows:

1. After defoliation, there was a higher proportion of tissue such as meristem and leaf sheath in the lin. treatment than in the Sin. treatment. This suggests that the low initial N.A.R. in the lin. treatment could be explained by a higher ratio of respiration to assimilation.

2. The declining N.A.R. following the point of complete light interception was probably due to mutual shading of leaves and increased leaf age.

3. The higher maximum N.A.R. obtained in the lin. treatment could be attributed to the bulk of the leaves being at an optimum physiological age for maximum photosynthesis.

These results illustrate that the mutual shading of leaves and the increased leaf age that occur under long spelling adversely affect N.A.R. At advanced stages of growth the interplay of these factors is also associated with a decreased rate of growth.

The significance of leaf age on the growth rate of white clover is evident from the results being obtained from current experimental work at Grasslands Division, D.S.I.R. The work is concerned with the life expectancy of clover leaves growing under sward conditions and is aimed at determining the influence of this factor on growth rate, yield ceilings, and the turnover of symbiotically fixed nitrogen. Although the work is incomplete, preliminary results indicate that after defoliation the newly formed leaves open very quickly and form a canopy which intercepts a considerable amount of light. The petioles of the next crop of bud leaves elongate until the leaf bud passes through the existing canopy, after which the leaf opens. This process is continued so that original leaves are shaded to such an extent that photosynthesis is inhibited and they finally die. From bud emergence to death the time interval is approximately 30 days, and under long spelling leaf death is of such magnitude that the growth rate of white clover declines and finally becomes negligible. It is probable that similar results would be obtained from work on other species. From analyses made by Dr Butler of the Plant Chemistry Division, Palmerston North, these dead leaves have a total nitrogen percentage of approximately 2 . It is probable therefore that death of white clover leaves is also a significant factor in the turnover of symbiotically fixed nitrogen.

\section{References}

Black, J. N. (1955). A ust. J. Bid. Sci, 8, 330-43.

Black, J. N. (1957). Herb. Abs. 27, 89-98.

Blackman, G. E. and Templeman, W. G. (1938). Ann. Bot. Lond. (N.S.) 2, 76.5-91. 
Blackman, G. E. and Wilson, G. L. (195 / ). Aln, Bot. Lond. (N.S.) /5, 63-94.

Brougham, R. W. (1956). Aust. J, Agric. Rex 7, 377-387.

Brougham, R. W. (1957). Aust. J. Agric. Res. (in press).

Donald, C. M. (1951). A ust. J. Agric. Res. 2, 355-76.

Donald, C. M. (1956). Proc. 7th Int. Grass. Cong.

Mitchell, K. J. (1956). N.Z.J. Sci. Tech. 37A, 395-413.

Mitchell, K. J. and Coles, S. T. J. (1955). N.Z.J. Sci. Tech. 36A, 586-603.

Richardson, A. E. V., Trumble, H. C. and Shapter, R. E. (1932). Coun. Sci. Industr, Res. Aust. Bull. No. 66

Sears, P. D. (1949). Proc. 12th Mtg. Sheepfarmers, Massey Agric. Coll. Stapledon, R. G. ( 1924). Bull. Welsh PI. Breed. Sta. Ser. H. No. 3, 5-84.

Thomas, M. D. and Hill, G. R. (1949). Mon. Amer. Soc. Plant Physiol. Iowa State Coll. Press 1952.

Wagner, R. E. (1952). Bull. U.S. Dept. Agric. No. 1063.

Watson, D. J. (1956). Symposium on Growth of Leaves. University of Nottingham. 178-191.

\section{DISCUSSION}

Q. Could we have more detail on experimental techniques? For one thing, how was defoliation done? Was there only one defoliation, or more? What species were used in the graphs shown?

A. For most of these experiments the pasture used is under a system of rotational grazing for 6-9 months before the start of the experiment. The final defoliation is then made with a sickle bar mower. This is essential to get uniform recovery growth. Following this the experimental area is laid out with enough plots to enable replicated measurements to be made at different stages of regrowth. Individual plots are cut only once for yield measurements and are then discarded. The species used in the last graph were short-rotation ryegrass and white clover.

Q. Is the cutting interval standardised at one week?

A. No. The first graph shows a cutting interval of 4 days and work at present in progress involves daily cutting. This of course involves the use of a large area of pasture.

Mr Campbell: An L.A.I. of 5 and maximum growth appear to be associated, and a height of $5 \mathrm{in}$. would apply to a rotational grazing area. This may not apply to a set stocked area.

The material presented in the paper shows that there are species and seasonal variation in the L.A.I. associated with almost complete light interception (95 per cent. or over). The height of herbage shows the same variation, e.g., in mid-winter pure white clover at a height of about 2 in. with an L.A.I. of about 2 is sufficient to intercept 95 per cent. of the incident light. Under set stocked conditions tiller density is much higher than under rotational grazing and consequently an L.A.T. of say 5 would occur at a much lower height.

Mr Edmond: On the Hokowhitu turf plots at Palmerston North, 12,000lb. of D.M./acre equivalent was not uncommon under close cutting.

$\mathrm{Mr}$ Brougham: This would suggest that a considerable amount of leaf was present under this system of cutting and may have been sufficient to intercept a large percentage of the available light throughout the year. 